\title{
Changes in reproductive habitat of gray partridge after burning
}

\author{
CLAUDE NOVOA, SAMUEL DUMAS, AND ROGER PRODON
}

\begin{abstract}
Authors are game biologist and field assistant. Office National de la Chasse, Direction de la Recherche et du Développement, Bd de la Gare, 66500 Prades, France, and assistant professor, Laboratoire Arago, Universite Paris 6 (URA CNRS 2126), B.P. 44, 66651 Banyuls-sur-Mer, France.
\end{abstract}

\section{Abstract}

We investigated the effects of winter controlled burning on the breeding habitat of the Pyrenean gray partridge (Perdix perdix hispaniensis Reich.). Floristic composition and vegetation structure were sampled on 198 sites, including 64 recently used by hens for nesting or rearing of broods, 90 within partridge habitat burned under dry conditions, and 44 burned under wet conditions.

During the early breeding season, birds selected shrublands of broom (Cytisus purgans (L.) Boiss.) with an average canopy coverage of $60 \%$ and an average height of $0.50 \mathrm{~m}$. Birds avoided sites where shrub cover was more than $80 \%$ or less than $20 \%$.

The most critical effect of burning on gray partridge brood habitat was the reduction of the cover in the 2 vegetation layers providing protection against predators $(0.05-0.25 \mathrm{~m}$, and $0.25-0.50 \mathrm{~m}$ ). In the case of "dry burning", the recovery of suitable habitat took more than 8 years for nesting hens and flightless chicks, but only 5-6 years for broods older than 3 weeks. Data obtained by radio-tracking eight broods indicated that "wet burns" (mean size $=4 \mathrm{ha}$ ) were better than "dry burns" (mean size = 15 ha) for maintaining good brood habitat. For the "dry burns", we recommend that burned patches be equal to or less than 5 ha and separated by unburned patches of 10-15 ha. In both cases, the frequency of fires should not exceed once every 15-20 years.

Key Words: Pyrenean gray partridge (Perdix perdix hispaniensis), broods, winter burns, Pyrenees, France

In Europe, the gray partridge lives in both lowland and mountain habitats. The latter are to be found in the southern parts of the species' distribution range i.e. the French Massif Central, the Cantabrics and the Pyrenees. The habitat of the Pyrenean partridge (Perdix perdix hispaniensis Reich.) is characterized by high elevations $(1,200-2,300 \mathrm{~m})$ and by lack of cultivated areas (Lescourret 1988). In the past, this partridge habitat in the Pyrenees was kept open by burning and grazing (Braun Blanquet 1948). In the eastern Pyrenees, the decline of grazing during the last 20 years has resulted in a subsequent increase of broom (Cytisus purgans (L.) Boiss.) and for this reason controlled burn-

\footnotetext{
The authors wish to thank R. Delmas, C. Agnes and J. Resseguier for field assistance. L.N. Ellison and P. Rogers made helpful comments on the manuscript. This work was supported by the Office National de la Chasse, the Service Interdépartemental Montagne Elevage Languedoc Roussillon and the Societe d'Elevage des Pyrénées-Orientales.

Manuscript accepted 3 Jan. 1998.
}

\section{Resumen}

Investigamos el efecto del fuego invernal controlado sobre el hábitat de cría de la perdiz pardilla del Pirineo (Perdix perdix hispaniensis). Se tomaron muestras de la composición florística y estructura de la vegetación en 198 localidades, las cuales incluían 64 usadas recientemente por hembras para anidar 0 criar, 90 situadas en el hábitat de la perdiz quemado bajo condiciones secas y 44 en el hábitat de la perdiz quemado bajo condiciones húmedas.

Durante la época de cría temprana, las aves seleccionaron matorral de retama (Cytisus purgans) con una cobertura media del $60 \%$ y una altura media de $0,50 \mathrm{~m}$. Las aves evitaron localidades donde el recubrimiento de matorral era mayor del $80 \%$ y menor del $20 \%$. El efecto más crítico del fuego sobre el hábitat de nidificación de la perdiz pardilla, fue la reducción de la cobertura de dos estratos de vegetación que ofrecen protección frente a los depredadores $(0,05-0,25 \mathrm{~m}$ y 0,25-0,50 m). En el caso del "quemado seco" la recuperación de un hábitat adecuado para hembras ponedoras y pollos no-volanderos tardó 8 años, aunque para nidadas de más de 3 semanas tardó sólo 5-6 años. Los datos obtenidos a partir 8 nidadas radio-marcadas os indicaron que los "quemados húmedos" (tamaño medio $=4 \mathrm{ha}$ ) fueron mejores que los "quemados secos" (tamaño medio = 15 ha) para mantener un buen hábitat de cría. Para los "quemados secos" recomendamos que las manchas quemadas sean igual o inferiores a las 5 ha y separadas por manchas no quemadas de 10-15 ha. En ambos casos, la frecuencia de fuegos no debería exceder de una cada 15-20 años.

ing is practiced by cattlemen to limit the invasion of grasslands by shrubs. This burning is usually done in winter, when the snowy or wet conditions reduce the danger of a wildfire and limit the impact of fire on grasses and forbs. Moreover, woody plants, especially broom, are more flammable during the colder months (Lambert and Parmain 1990).

Although burnings are generally considered to be harmful to the gray partridge (Lucio et al.1992), the relationships between fire and partridge populations have rarely been studied, unlike for other upland game birds such as quail or grouse. Most of the authors reviewing these questions have emphasized the importance of the type of fire. For example, large fires (e.g. burning under dry meteorological conditions) generally decrease the availability of nesting cover for upland birds (Bendell 1974, Peek 1986). Conversely, low-intensity controlled burning (e.g. burning 
under wet conditions) can improve edge and interspersion (Payne and Bryant 1994). The effects of burning on quantity and quality of food resources are more complex, and the benefits are more evident for ungulates than for upland birds (Payne and Bryant 1994). Nevertheless, burning can improve habitats of birds by increasing production of seeds and insects, and by making food more accessible (Koerth et al.1986, Prodon and Pons 1993).

The present paper addresses the following questions concerning the effect of fire on brood habitats of gray partridge. What is the impact of controlled burning on the structure and floristic composition of vegetation? How long is the recovery period before the return of suitable brood habitats? Does the impact of burning differ for wet and dry conditions?

\section{Study Area}

The study was conducted on 3 areas of the eastern French Pyrenees $\left(1^{\circ} 54^{\prime}-2^{\circ} 29 \mathrm{E}, 42^{\circ} 31^{\prime}-42^{\circ} 42^{\prime} \mathrm{N}\right)$. Two of them (Barbet and Carlit) were very similar, and typical of the open subalpine zone. Their altitude ranged from 1,700 to $2,300 \mathrm{~m}$ on south-facing slopes, and vegetation was dominated by a mosaic of shrubs (Cytisus purgans, Juniperus communis L., Arctostaphylos uva-ursi (L.) Spreng.), grasslands (Festuca rubra L., F. eskia Ramond, $F$. paniculata (I.) Schinz et Thell.) and pine woods (Pinus uncinata Ramond). The third study area, situated at a lower elevation $(1,400-1,850 \mathrm{~m})$, was a typical montane zone. The main difference from the previous areas was the prevalence of heather (Calluna vulgaris (L.) Hull) and bilberry (Vaccinium myrtillus L.).

The climate of the 3 areas is continental (Izard et al. 1985). At $1,700 \mathrm{~m}$, mean annual temperature is $6^{\circ} \mathrm{C}$ and mean annual precipitation is $820 \mathrm{~mm}$, with winters being relatively dry. On all 3 study areas, cattle grazing was limited to June through October, and the grazing pressure varied between 0.5 and 1.4 AUM per ha.

\section{Methods}

\section{Sampling Design}

Pointing dogs and radio-tracking were used to locate birds. From 1989 to 1996,64 reproductive sites ( 6 nests, 36 broods less than 3 weeks old, 22 broods more than 3 weeks old) were found on the 3 study areas. Because nest sites were always included in the home ranges of broods, the 6 nest sites were grouped with the sites of broods less than 3 weeks old.

Twenty-two controlled burnings were carried out on the 3 study arcas between 1989 and 1995 to improve grasslands (Table 1). These burns were considered to be potential reproductive habitat, because broods were observed on them before burning. The controlled burns were mainly headfires carried out in winter, from November to March, under either dry meteorological conditions or under wet conditions (ground partly covered by snow or atmospheric humidity high). These conditions largely determined the size and distribution of burned patches.

Within these 22 burns, we selected 134 sites at random: 90 in "dry burns" and 44 in "wet burns" where vegetation samplings were carried out from 1993 to 1996 (Table 1). The vegetation sampling of each of the 64 brood sites was made shortly after broods were located on the sites (i.e. within a month).

Plant species were listed within a $25-\mathrm{m}$ radius area around each site, and the elevation was recorded. The habitat structure was described in 3 ways:

(1) The percentage cover of trees $(>1.5 \mathrm{~m}$ tall) and shrubs $(<1.5$ $m$ tall), and that of herbaceous plants and bare ground ( 4 variables), were estimated by comparison with a reference chart (Prodon and Lebreton 1981). The average height of shrubs and herbaceous plants ( 2 variables) was also measured.

(2) The vegetation was sampled along two 50 -m lines that crossed perpendicularly on the center of the site (Bernard 1982) (Fig. 1). Every 2 meters, the presence/absence of vege-

Table 1. Chronology of vegetation samplings on burning sites according to meteorological conditions, size and age of controlled burnings.

\begin{tabular}{|c|c|c|c|c|c|c|c|c|c|c|c|}
\hline \multirow[b]{2}{*}{$\mathrm{n}^{\circ}$} & \multicolumn{3}{|c|}{ Controlled burning } & \multicolumn{8}{|c|}{$\begin{array}{l}\text { Chronolgy of vegetation samplings }(\bullet) \\
(1=\text { first summer after burning... })\end{array}$} \\
\hline & conditions & size & date & 1. & 2 & 3 & 4 & 5 & 6 & 7 & \multirow[t]{2}{*}{8} \\
\hline & & (ha) & (month/year) & & & & & & & & \\
\hline 1 & Dry & 22 & $01 / 89$ & - & - & - & - & $\bullet$ & $\bullet$ & - & - \\
\hline 2 & $\because$ & 9 & $01 / 89$ & - & - & - & - & - & - & - & - \\
\hline 3 & $“$ & 9 & $02 / 89$ & - & - & - & - & - & $\bullet$ & - & - \\
\hline 4 & “ & 12 & $01 / 91$ & - & - & - & - & $\bullet$ & $\bullet$ & - & - \\
\hline 5 & “ & 17 & $02 / 91$ & - & - & - & - & $\bullet$ & - & - & - \\
\hline 6 & " & 34 & $01 / 92$ & - & - & - & $\bullet$ & - & - & - & - \\
\hline 7 & $"$ & 11 & $02 / 92$ & - & $\bullet$ & - & $\cdot$ & - & - & - & - \\
\hline 8 & $"$ & 32 & $01 / 93$ & $\bullet$ & - & - & - & - & - & - & - \\
\hline 9 & " & 19 & $11 / 93$ & $\bullet$ & • & - & - & - & - & - & - \\
\hline 10 & $"$ & 13 & $03 / 94$ & - & • & - & - & - & - & - & - \\
\hline 11 & “ & 4 & $03 / 94$ & - & • & - & - & - & - & - & - \\
\hline 12 & $"$ & 16 & $03 / 94$ & $\bullet$ & - & - & - & - & - & - & - \\
\hline 13 & $"$ & 7 & $02 / 95$ & • & - & - & - & - & - & - & - \\
\hline 14 & $"$ & 4 & $02 / 95$ & $\bullet$ & - & - & - & - & - & - & - \\
\hline 15 & Wet & 1 & $02 / 91$ & - & - & - & - & - & - & - & - \\
\hline 16 & “ & 2.5 & $02 / 92$ & - & - & • & • & - & - & - & - \\
\hline 17 & $"$ & 3 & $01 / 93$ & - & • & - & - & - & - & - & - \\
\hline 18 & “ & 11 & $11 / 93$ & • & • & - & - & - & - & - & - \\
\hline 19 & " & 4.5 & $12 / 93$ & • & • & - & - & - & - & - & - \\
\hline 20 & $"$ & 6 & $03 / 94$ & • & • & - & - & - & - & - & - \\
\hline 21 & $"$ & 2 & $03 / 94$ & - & $\bullet$ & - & - & - & - & - & - \\
\hline 22 & " & 3 & $02 / 95$ & $\stackrel{\bullet}{-}$ & - & - & - & - & - & - & - \\
\hline
\end{tabular}


tation was noted within five layers: $0-0.05 \mathrm{~m}, 0.05-0.25$ $\mathrm{m}, 0.25-0.50 \mathrm{~m}, 0.50-1 \mathrm{~m}, 1-2 \mathrm{~m}$. A cover index was calculated for each layer ( 5 variables) by adding together the number of contacts recorded. A global index of foliage volume was then obtained by summation of products of the height of each layer times its cover index (Fig. 1).

(3) At the center of each site, 2 measurements ( 2 variables) of the concealment offered by the vegetation were made using a cover board, viewed from a $45^{\circ}$ angle above the ground and from ground level or $0^{\circ}$ (Jones 1968, Bernard 1982).

To evaluate the effects of size of burns on brood habitat, we needed information on the extent of home ranges used by the birds. We employed a core convex polygon model with $95 \%$ of radio fixes (Kenward 1987) to calculate the area of home ranges of 8 gray partidges radio-tracked from egg-laying (early June) to the third week after hatching (early or mid-August).

\section{Statistical Analysis}

The floristic composition of brood and burned sites (198 sites $X 125$ plant species) was analyzed by Correspondence Analysis (C.A.), using Biomeco Software (Lebreton et al. 1990). The floristic composition of the different categories of sites was estimated by calculating their mean scores on the F1-axis. The floristic diversity of each site was estimated by calculating the variance of plant scores on the first factor of the C.A. (Chessel et al. 1982, Thioulouse and Chessel 1992). These mean scores and variances were then compared (one-way ANOVA) to test whether both floristic composition and floristic diversity were different from brood to burned sites on the one hand, and according to the wet or dry conditions of burning on the other hand.

Another approach was to extract, from the 14 quantitative variables describing the elevation and the habitat structure, a habitat description over a reduced space, on which the different categories of sites could be plotted (Rotenberry and Wiens 1980). Thus, the matrix of the 14 variables $\times 198$ sites was analyzed by

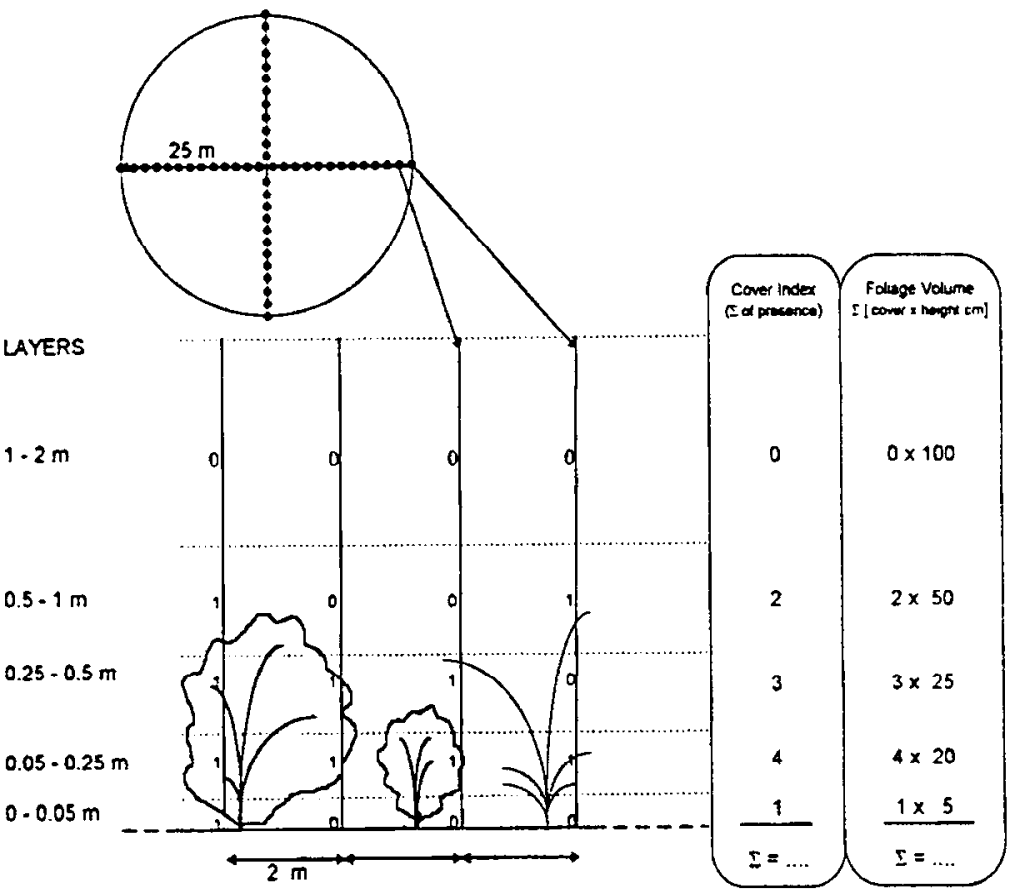

Fig. 1. Procedure for sampling vegetation cover around a brood or burned site. The presence/absence of vegetation is noted in five different layers, every 2 meters, along two $50-\mathrm{m}$ perpendicular lines (52 points).
Principal Components Analysis (P.C.A.), and the main factors were interpreted by examining their correlations with the variables. We only plotted the sites when the sum of cosines squared on F1 and F2 axes was greater than 0.10 (see Fenelon 1981).

Independently of these 2 multivariate analyses, the elevations of brood and burned sites were compared using a KolmogorovSmirnov two-sample test (Sokal and Rohlf 1981).

\section{Results}

\section{Changes in floristic composition}

The correspondence analysis showed that floristic composition differed between brood and burned sites. The mean score of brood sites on the $\mathrm{F} 1$-axis differed from that of burned sites $(\mathrm{F}=$ 41.04 , d.f. $=1,196, P<0.001$ ) and the factorial diversity (i.e. floristic diversity) of the brood sites $(n=64)$ was significantly higher than that of the burned sites $(n=134)$ (one-way ANOVA $F=4.99$, d.f. $=1,196, P=0.03$ ). Nevertheless, the mean $F 1$ scores and the factorial diversity did not differ between "wet burns" $(n=44)$ and "dry burns" $(n=90)$ (one-way ANOVA, $F=$ 0.20 , d.f. $=1,132, P=0.65$, and $F=0.21$, d.f. $=1,132, P=0.65$, respectively).

As controlled burning is not practiced so much in high altitude and/or damp sites, some plant species characteristic of these situations were not recorded in burned sites. This leads us to think that the greater floristic diversity of the brood sites compared to burned sites is related more to their distribution over a wide range of altitudes than to an actual reduction of floristic diversity after burning.

We noted, however, that the frequency of occurrence of 28 of 116 plant species recorded within the same altitude range differed between brood and burned sites (Table 2). Some plants important for food and/or cover in autumn such as Arctostaphylos uva-ursi, Calluna vulgaris, Festuca paniculata, Trifolium sp. and Vaccinium myrtillus had a lower frequency in the burned sites. Conversely the higher frequency of Anthoxanthum odoratum, Agrostis capillaris, Festuca ovina, and Galium pumilum in the burned sites might improve winter food resources.

\section{Changes in vegetation structure after burning}

The elevation of burned site ranged from $1,590 \mathrm{~m}$ to $2,200 \mathrm{~m}$, differing only slightly from that of the brood sites $(1,500$ to 2,290 m) (Kolmogorov-Smirnov test, $\mathrm{D}=0.227>\mathrm{D} 0.05=0.205$ ). However, this difference did not affect the results of the P.C.A., owing to the low contribution of this variable (Fig. 2).

The main changes in brood habitat occurring after burning concerned the vegetation structure. To illustrate this process, we distributed sites in post-fire age classes and plotted separately each category of sites on the F1-F2 plane of the P.C.A. (Figs. 3, 4). The most important feature was the postfire decrease of woody plant height and cover $(0.05-0.25 \mathrm{~m}$ and $0.25-0.50 \mathrm{~m}$ layers), indicated by a shift of the sites along Fl axis. The concealment offered by vegetation (i.e. protection against predators) was also correlated with F1.

Another important feature was the increase of grass and forb cover the first years after burning ( $51 \%$ after $1-4$ years vs. 34\% for the brood sites), marked by a shift along $F 2$ axis. Thus the discrimination between the groups of sites clearly appeared on the F1-F2 plane, the postfire modifications being more marked for the "dry burns" (Figs. 3, 4). 
Table 2. Frequency of occurrence (\%) of 28 plants on the gray partridge brood sites $(n=64)$ and on the burned sites [dry conditions $(n=90)$ or wet conditions $(n=44)$ ]. The frequencies of the other plant species $(n=$ 88) did not vary between burned and unburned sites.

\begin{tabular}{|c|c|c|c|c|}
\hline \multirow[b]{3}{*}{ Species } & \multicolumn{3}{|c|}{ Controlled burning } & \multirow[b]{3}{*}{ Trend } \\
\hline & \multirow{2}{*}{$\begin{array}{l}\text { Brood } \\
\text { habitat }\end{array}$} & \multirow{2}{*}{\multicolumn{2}{|c|}{$\begin{array}{c}\text { Dry Wet } \\
\text { conditions conditions }\end{array}$}} & \\
\hline & & & & \\
\hline Shrubs & $(\%)$ & $(\%)$ & $(\%)$ & \\
\hline Arrtostaphylos uva-ursi & 20 & 10 & 11 & $x$ \\
\hline Calluna vulgaris & 59 & 26 & 25 & $x$ \\
\hline Juniperus communis & 61 & 12 & 43 & $x$ \\
\hline Genista pilosa & 6 & 1 & 0 & $>$ \\
\hline Vaccinium myrtillus & 41 & 16 & 16 & $x$ \\
\hline Rosa canina & 23 & 51 & 39 & $\pi$ \\
\hline \multicolumn{5}{|l|}{ Grasses } \\
\hline Deschampsia coespitosa & 6 & 2 & 0 & $x$ \\
\hline Festuca paniculata & 36 & 22 & 11 & $x$ \\
\hline Anthoxantum odoratum & 9 & 20 & 20 & 入 \\
\hline Agrostis capillaris & 47 & 72 & 89 & 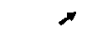 \\
\hline Festuca ovina & 22 & 37 & 52 & 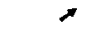 \\
\hline \multicolumn{5}{|l|}{ Forbs } \\
\hline Bupleurum ranunculö̈des & 6 & 1 & 2 & $x$ \\
\hline Epilobium angustifolium & 17 & 9 & 0 & $x$ \\
\hline Trifolium alpinum & 20 & 2 & 11 & $x$ \\
\hline Trifolium pratense & 6 & 0 & 0 & $x$ \\
\hline Trifolium repens & 14 & 4 & 7 & $y$ \\
\hline Biscutella laevigata & 2 & 13 & 18 & $x$ \\
\hline Cirsium sp. & 16 & 31 & 34 & 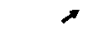 \\
\hline Euphorbia cyparissias & 9 & 26 & 18 & 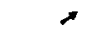 \\
\hline Galeopsis Pyrenaica & 14 & 39 & 25 & $\pi$ \\
\hline Galium pumilum & 5 & 19 & 11 & 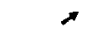 \\
\hline Jasione perennis & 2 & 17 & 25 & ر \\
\hline Linaria siriata & 11 & 47 & 25 & \\
\hline Rhinanthus minor & 3 & 21 & 9 & 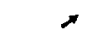 \\
\hline Senecio adonidifolius & 22 & 49 & 39 & - \\
\hline Scabiosa columbaria & 5 & 14 & 30 & $x$ \\
\hline Verbascum thapsus & 6 & 13 & 18 & 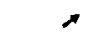 \\
\hline Viola sp. & 11 & 16 & 34 & $\pi$ \\
\hline
\end{tabular}

On the 42 sites of broods less than 3 weeks old, the shrub covers ranged from 50 to $80 \%$ on 28 of the sites. Shrub cover was superior to that of grasses plus forbs $(57 \% \pm 3$ SE vs. $34 \% \pm 3$ $\mathrm{SE})$. On the 22 sites of broods more than 3 weeks old, shrub cover and herbaceous plant cover tended to be equal $(44 \% \pm 5 \mathrm{SE}$ vs. $46 \% \pm 5 \mathrm{SE}$ ). The shrub canopy height did not vary between the 2 categories of broods $(0.50 \mathrm{~m} . \pm 0.02$ vs, $0.46 \mathrm{~m} . \pm 0.03)$. Thus, the cover requirement of young broods, unable to fly, appeared to be more important than for older broods. Older broods tended to use more open and herbaceous lands. The concealment indices obtained with the board viewed at $45^{\circ}$ and $0^{\circ}$ were $24 \%$ and $55 \%$ respectively on the burned sites vs. $60 \%$ and $86 \%$ on the brood sites. The low concealment index of the herbaceous cover was due to the fact that the height of grasses and forbs averaged only $0.25 \mathrm{~m}$.

\section{Vegetation recovery}

Data from different age classes of postfire sites showed a gradual return of cover, more evident on $F 2$ than on $F 1$ axes. The recovery of suitable conditions for the broods older than 3 weeks required an average of 5-6 years after burning, vs. more than 8 years for non-flying broods (Fig. 3), as confirmed by the variations of the foliage volume index (Fig. 5). In the case of "dry burns", 8 years after burning the average cover and height of shrubs reached respectively $37 \%$ and $0.43 \mathrm{~m}$. Thus, a minimum of about 10 years seems to be necessary for the regrowth of good brood habitat (see Fig. 5). The persistence of a suitable vegetation cover appears to be better in "wet burns", even 1 or 2 years after burning (Fig. 4).

\section{Discussion and Management implications}

The full extent of the effects of controlled burning on floristic composition of shrublands and consequently on food resources
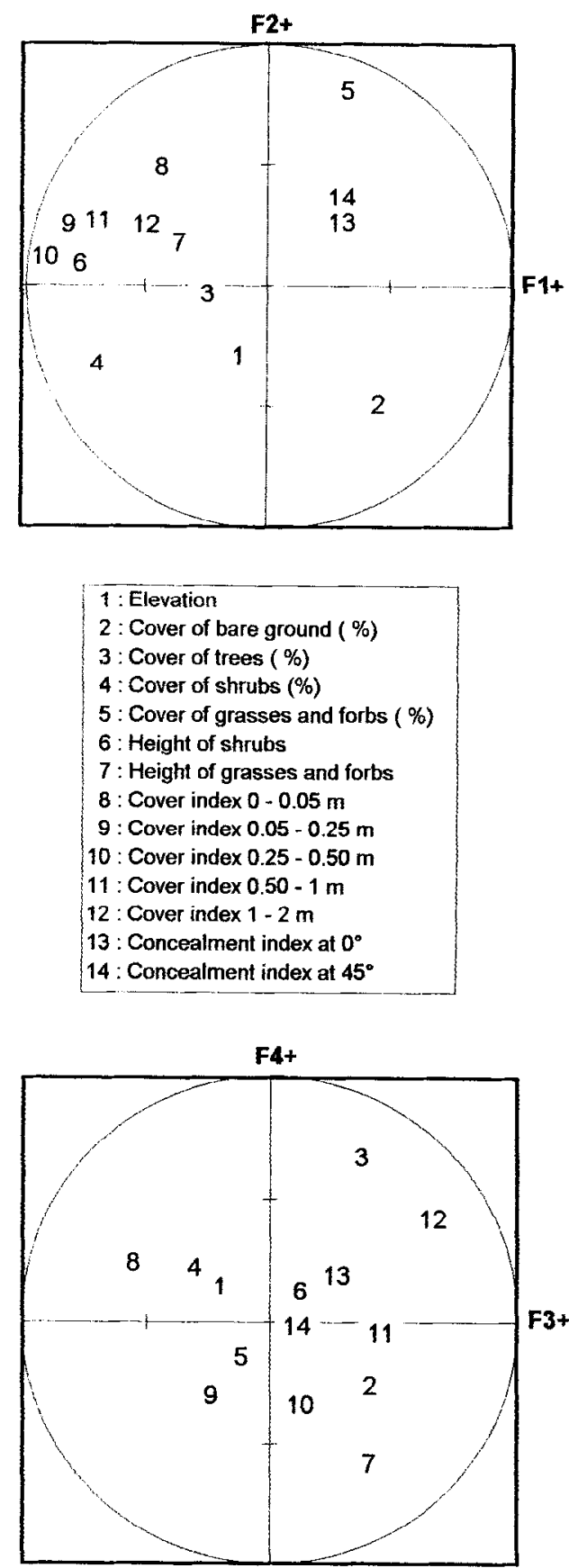

Fig. 2. Correlation plots of the 14 variables with the F1 $\times F 2$ and F3 $\times$ F4 planes of the Principal Components Analysis. [Contributions of axes : F1(32.3\%), F2 (13.2\%), F3 (11.3\%), F4 (10\%)]. 

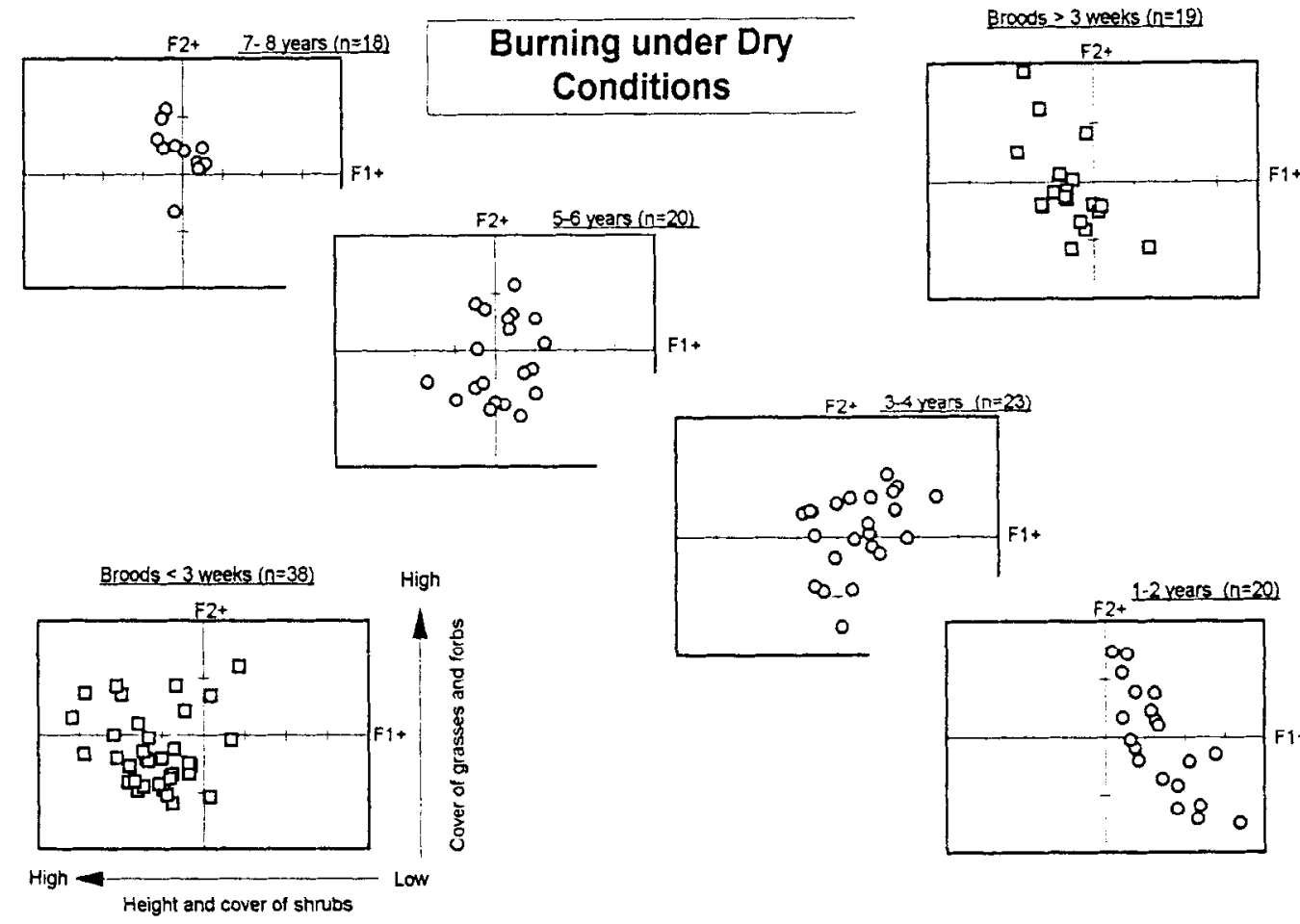

$$
\text { height and cover of shubs }
$$

Fig. 3. Recovery of the brood habitat of the gray partridge after controlled burning under dry conditions. Projection of 6 site categories on the F1-F2 plane of the P.C.A.: brood sites ( 2 categories) and burned sites (4 categories). ( $n=$ number of sites plotted).

for gray partridges was difficult to assess in our study. The floristic diversity of the burned sites was lower than that of brood sites, mainly because of the narrow altitude range of burned sites. Nevertheless, this floristic diversity may also have been reduced by the recurrence of fires throughout the first half of the century (Fridlender 1991).

One possible conclusion concerning food resources would be that the decrease of some important food plants could be balanced by an increase in other species, such as grasses for winter and spring food (for a review, see Birkan 1970). One positive effect of fire on food resources could be that, in the aftermath of fires, the new growth could furnish a high protein diet just before egg-laying. Fire has this beneficial effect on red grouse (Lagopus l. scoticus) on heather moorlands (Moss et al. 1972). The effect of fire on insect fauna, the main food resource of young chicks, remains to be investigated.

The importance of cover for successful nesting and rearing of broods has been emphasized for numerous game birds (Bernard 1982, Rands 1988, Ricci et al. 1990, Riley et al. 1992). Good nesting cover promotes both nest success and high chick survival, 2 key factors of gray partridge demography (Potts and Aebischer 1994). The density of cover reduces prey vulnerability (Bendell 1974). Very heavy and very light cover likely increases the vulnerability of partridge to both mammalian predators and raptors. As a result, a woody plant cover of about $60 \%$ is an important feature of the breeding habitat of the Pyrenean gray partridge, which seems to avoid sites where the canopy coverage in the shrub layer is more than $80 \%$ or less than $20 \%$. A preference for moderate woody plant cover has been previously reported for the Pyrenean gray partridge (Lescourret and Génard 1993). In northern Spain, Lucio et al. (1996) also found a predilection for shrublands of Genista obtusiramea, G. florida, Cytisus purgans and $C$. scoparius, with an average cover of $70 \%$.

The most negative effect of burning on brood habitat is the reduction of shrub cover. Suitable habitat for broods is more likely to remain following "wet burns" than "dry burns". A major factor in wildlife response is the extent of fire (Peek 1986). In Spain, large fires reduce the carrying capacity of a landscape for gray partridge (Lucio et al. 1992). In the French Pyrenees, fires set in winter under moist conditions lead to smaller burns (mean $=4 \mathrm{ha}$ ) than do those set under dry conditions (mean $=15 \mathrm{ha}$ ). "Wet burns" therefore favor a fine-grained mosaic of grassy openings, with some bare ground, interspersed within the unburned shrubland. Such a fine-grained habitat is also recommended for improving red grouse habitat in the Scottish heather moorlands (Picozzi 1968, Moss 1989). Large fires create an unfavorable coarse-grained habitat for both gray partridge and red grouse. Large clearcuts in Scandinavian forests have a similar negative effect on capercaillie (Tetrao urogallus) (Rolstad and Wegge 1987). The definition of grain size of habitats obviously depends on the requirements of the species studied. Using the ruffed grouse (Bonasa umbellus) as an example, Gullion (1972) proposed that home range size is an indicator of size of clearcuts or burns most suitable for a species. For the Pyrenean gray partridge, home range size during the breeding period ranged from 4 to 23 ha (mean $=12$ ha). Hence, the minimum requirement for maintaining suitable breeding conditions would be to leave unburned areas of 10-15 ha between the burned patches. Burns should not be larger than 5 ha, though it is difficult to control such fires precisely under dry conditions.

After burning under dry conditions, the recovery of a foliage volume comparable with that of brood sites less than 3 weeks old requires about 10 years. In the Massif Central of France, the canopy coverage of broom in shrublands situated below $1,600 \mathrm{~m}$ 

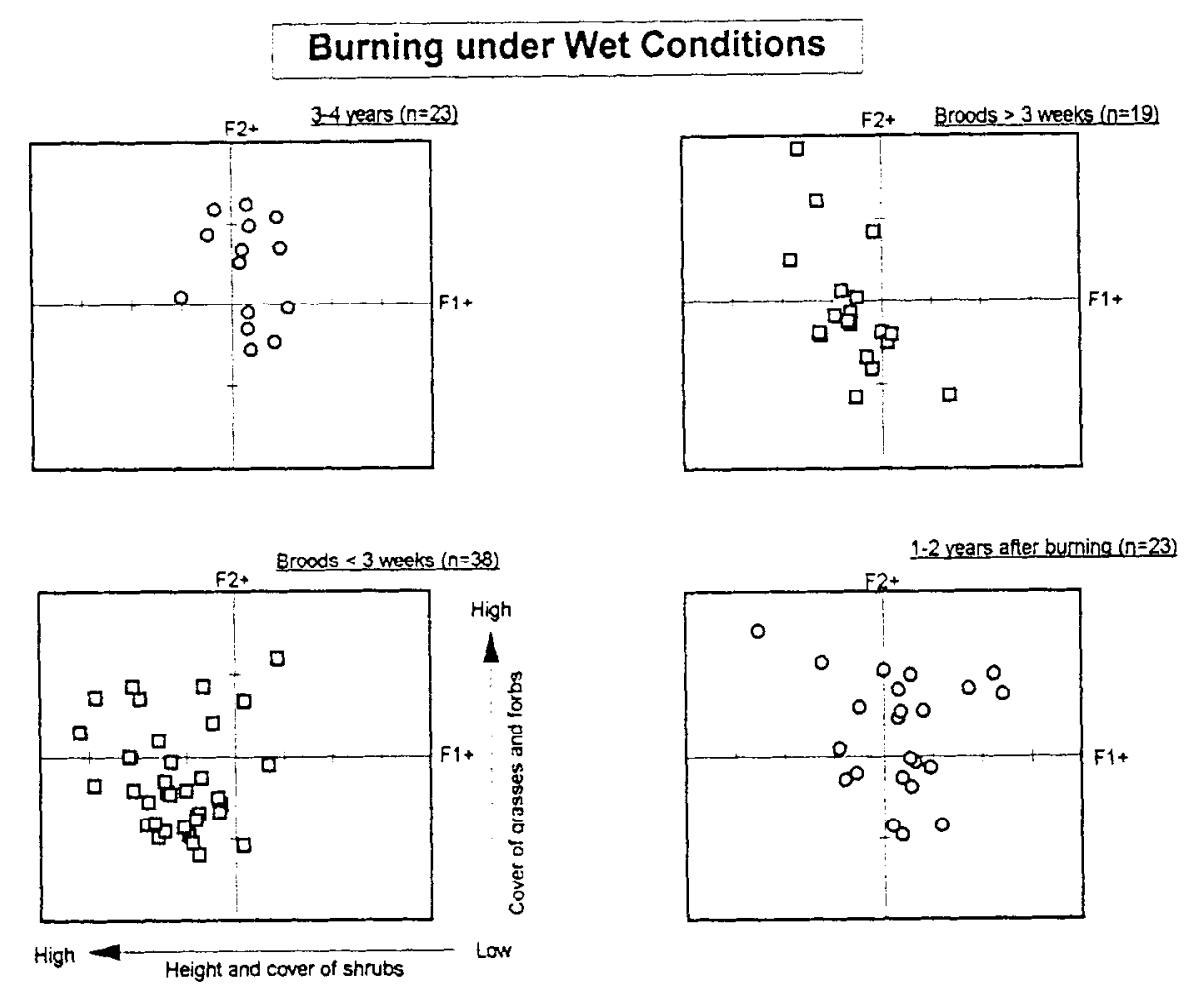

Fig. 4. Recovery of the brood habitat of the gray partridge after controlled burning under wet conditions. Projection of 4 site categories on the F1-F2 plane of the P.C.A.: brood sites ( 2 categories) and burned sites ( 2 categories). ( $n=$ number of sites plotted).

reaches $100 \%$ only 10 years following burning (Debussche 1978). The high elevation of our sites probably explains the long recovery period. Other factors such as precipitation following burning (Peek 1986) and grazing pressure could affect vegetational response to fire, as well as the recovery period. In all cases, the frequency of fires should not be more than once every 15-20 years. Only 2 of 42 broods less than 3 weeks old were found in areas burned under dry conditions: one brood 2 years after burning, the other 6 years after burning. Older broods apparently require less dense cover than do young broods. Four of 22 broods more than 3 weeks old were found in areas burned under dry conditions, one of them in the first summer after burning. The colonization of burns by gray partridges seems to be slower than that in red-legged partridges, which readily breed in burns 2 or 3 years old (Prodon 1987, Ricci et al. 1990).

The invasion by shrubs following a decrease in grazing pressure seems to be rather favorable in the short term for gray partridge brood habitat (see also Lescourret and Génard 1993). At this successional stage, diversity of the vegetation structure of the shrubland is highest (Debussche 1978, Lucio et al. 1996). However, in the long term, the woody/herbaceous plant ratio tends to decrease (Dumas 1995), and the natural vegetation dynamics will lead to the progressive replacement of broom shrublands by pine-woods of Pinus uncinata. In the eastern Pyrenees, grazing pressure is currently not heavy enough to prevent this natural vegetation succession.

Thus, the long-term persistence of open landscapes for gray partridge in the Pyrenees, as well as for red grouse in Scotland (Moss 1989, Hudson 1992) and bobwhite quail (Colinus virginianus) in North America (Roseberry and Klimstra 1984) depends on controlled burning. Some measures can be taken to limit the negative impact of fire on gray partridge brood habitat in broom communities. Ideally, burning should be done when the ground is partly covered by snow and/or the atmosphere is damp. However, these meteorological conditions are not always present. Moreover burning under wet conditions is very time-consuming, and so is less frequently practiced. If burning must be done under dry conditions, the conservation of gray partridge habitat requires the burning of broom in patches smaller than 5 ha, while leaving unburned adjoining patches of 10-15 ha. Because recovery of partridge habitat after fire is slow, the rotation period of burning should be about $15-20$ years.

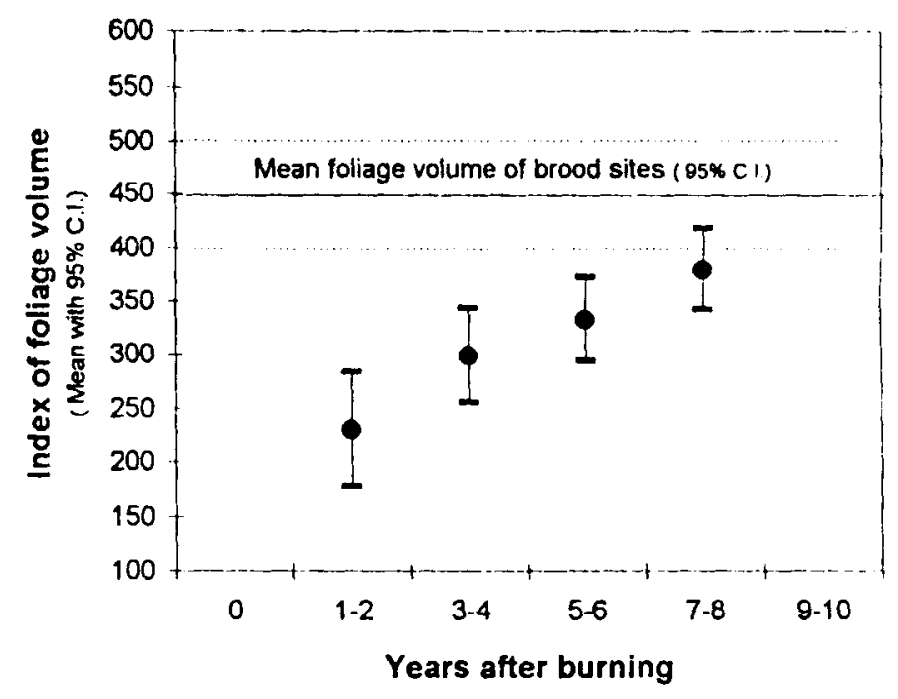

Fig. 5. Vegetation recovery in a broom-juniper shrubland after winter controlled burning in dry conditions. (Index of foliage volume = sum of the products of the heights of each layer by their relative cover indices). 


\section{Literature Cited}

Bendell, J. F. 1974. Effects of fire on birds and mammals. p.73-138 In: T.T. Kozlowski and C.E. Ahlgren (eds.), Fire and Ecosystems. Academic Press, New York, N.Y.

Bernard, A. 1982. An analysis of black grouse nesting and brood habitats in the French Alps. p. 49-59 In: Lovel T.W.I (ed.) Symp. on Grouse 2.

Birkan, M. 1970. Le régime alimentaire de la perdrix grise d'aprés les contenus des jabots et des estomacs. Ann. Zool. Ecol. Anim. 2:121-153.

Braun-Blanquet, J. 1948. La végétation alpine des Pyrénées-Orientales. Monografía de la Estación de Estudios Pirenaicos. Jaca. Spain.

Chessel, D., J.D. Lebreton, and R. Prodon. 1982. Mesures symétriques d'amplitude d'habitat et de diversité intra-échantillon dans un tableau espèces-relevés : cas d'un gradient simple. C.R. Acad. Sc. Paris 295:83-87.

Debussche, M. 1978. Etude de la dynamique de la végétation sur le versant nord-ouest du Mont Aigoual. Doc. $\mathbf{n}^{\circ}$ 87, CNRS, Montpellier.

Dumas, S. 1995. Quelles incidences sur la perdrix grise des Pyrénées de l'utilisation des bralages dirigés dans l'aménagement pastoral ? ONCCIMA, Univ. Toulouse Mirail, France.

Fenelon, J.P. 1981. Qu'est-ce que l'analyse des données? Lefonen. Paris.

Fridlender, A. 1991. De l'étude systématique des genêts à la compréhension des landes à Cytisus purgans. CIMA-CNRS, Univ. Toulouse Mirail, France.

Gullion, G.W. 1972. Improving your forested lands for ruffed grouse. Minn. Agr. Expt. Sta. Misc. J. Ser. Publ. No. 1439.

Hudson, P. J. 1992. Grouse in space and time. The population biology of a managed gamebird. The Game Conservancy, Fordingbridge, UK.

Izard, M., H. Casanova, B. Devau, and G. Pautou. 1985. Continentalité et notion de zone interne dans les Pyrénées. Oecol. Gener. 6:317-344.

Jones, R.E. 1968. A board to measure cover used by prairie grouse. J. Wildl. Manage. 32:28-31.

Kenward, R. 1987. Wildlife radio tagging. Academic Press, London.

Koerth, B.H., J.M. Mutz, and J.C. Segers. 1986. Availability of bobwhite foods after burning of pan American Balsamscale. Wild. Soc. Bull. 14:146-150.

Lambert, B., and V. Parmain. 1990. Les brâlages dirigés dans les Pyrénées-Orientales. Rev. For. Fr. XLII:141-155.

Lebreton, J.D., M. Roux, A.M. Bacou, and G. Banco. 1990. Biomeco (Biométrie-écologie), version 3.9, CNRS-CEFE Montpellier, France.

Lescourret, F. 1988. Eléments de répartition de la perdrix grise (Perdix perdix hispaniensis Reich.) dans les Pyrénées francaises. Gibier Faune Sauvage 5:123-148.

Lescourret, F. and M. Génard. 1993. Habitat relationships of the Pyrenean gray partridge. J. Range Manage. 46:289-295.

Lucio, A.J., F.J. Purroy, and M.S. De Buruaga. 1992. La perdiz pardilla (Perdix perdix) en España. I.C.O.N.A., Madrid, Spain.

Lucio, A.J., F.J. Purroy, M.S. De Buruaga, and O. Llamas. 1996. Consecuencias del abandono agroganadero en areas de montaña para la conservacion y aprovechamiento cinegetico de las perdices roja y pardilla en España. Revista Florestal 9:305-318.

Moss, R. 1989. Management of heather for game and livestock. Botanical J. of the Linnean Society 101:301-306.

Moss, R., G.R. Miller, and Allen S.E. 1972. Selection of heather by captive red grouse in relation to the age of the plant. J. Appl. Ecol. 9:771-781.

Payne, N. F. and F.C. Bryant. 1994. Techniques for wildlife habitat management of uplands. McGraw-Hill, New York, N.Y.

Peek, J. M. 1986. A review of wildlife management. Prentice-Hall, New Jersey.

Picozzi, N. 1968. Grouse bags in relation to the management and geology of heather moors. J. Appl. Ecol. 5:483-488.

Potts, G.R. and N. J. Aebischer. 1994. Population dynamics of the Grey Partridge Perdix perdix 1793-1993: monitoring, modelling, and management. Ibis 137:29-37.
Prodon, R. 1987. Incendies et protection des oiseaux en France méditerranéenne. L'oiseau et R.F.O 57:1-12.

Prodon, R. and J.D. Lebreton. 1981. Breeding avifauna of a Mediterranean succession: The holm oak and corn oak series in the eastern Pyrenees. I. Analysis and modelling of the structure gradient. Oikos 37:21-38.

Prodon, R. and P. Pons. 1993. Postfire bird studies: methods, questions, and perspectives. p. 332-343 In: L. Trabaud and R. Prodon (eds.). Fire in Mediterranean Ecosystems. Ecosystems Res. Rep. Vol. 5, ECSCEEC-EAEC, Brussels.

Rands, M. R. W. 1988. The effect of nest site selection on nest predation in grey partridge Perdix perdix and red-legged partridge Alectoris rufa. Ornis Scandinavica 19:35-40.

Ricci, J. C., J.F. Mathon, A. Garcia, F. Berger, and J.P. Esteve. 1990. Effect of habitat structure and nest site selection on nest predation in red-legged partridges (Alectoris rufa L.) in French mediterranean farmlands. Gibier Faune Sauvage 7:231-253.

Riley, T. Z., C.A. Davis, M. Ortiz and M.J. Wisdom. 1992. Vegetative characteristics of successful and unsuccessful nests of lesser prairie chickens. J Wildl. Manage. 56(2): 383- 387.

Rolstad, J., and P. Wegge. 1987. Distribution and size of capercaillie leks in relation to old forest fragmentation. Oecologia 72:389-374.

Roseberry, J. L. and W.D. Klimstra. 1984. Population Ecology of the bobwhite. Southern Illinois University Press, Carbondale and Edwardsville.

Rotenberry, J.T. and J.A. Wiens. 1980. Habitat stucture, patchiness, and avian communities in North American steppe vegetation: a multivariate analysis. Ecol. 52:23-40.

Sokal, R.R. and F.J. Rohlf. 1981. Biometry. W.H. Freeman and Co., New York.

Thioulouse, J. and D. Chessel. 1992. A method for reciprocal scaling of species tolerance and sample diversity. Ecol. 73: 670-680. 